\title{
Relationship between Organizational Factors and Corporate Entrepreneurship: A Study of Iranian Small and Medium Enterprises
}

\author{
Mahmood Zohoori \\ Master of Environmental \\ Management \\ Putra University of Malaysia \\ Birjand, Iran
}

\author{
Ali Ghani \\ Master of Business \\ Administration (MBA) \\ Industrial Management Institute \\ Birjand, Iran
}

\author{
Hojat Zakeri \\ Master of Environmental \\ Pollution \\ Islamic Azad University, \\ Science and Research Branch, \\ Birjand, Iran
}

\begin{abstract}
The main purpose of this study is to examine the relationship between organizational factors and corporate entrepreneurship in Iranian SMEs. Organizational factors consist of management support, organizational values, organizational culture, formal control, work independency and empowerment, environmental monitoring, and organizational communication. 251 data gathered from 50 Iranian SMEs. The result of multiple regression analysis showed that all factors have significant and positive effects on corporate entrepreneurship. The highest impact referred to work independency and empowerment while the lowest impact referred to organizational culture.
\end{abstract}

Keywords: Corporate Entrepreneurship, Organizational Factors, SMEs, Iran

\section{INTRODUCTION}

Those companies which are participating in entrepreneurial activities can achieve more profit compared to other ones that are limited in such activities ( Antoncic \& Hisrich, 2001) (Mojica, et al., 2010) According to (Pearce II, et al., 2010), the corporate entrepreneurship results in a more profitable first-mover benefit. The modern business contexts include two main features which are uncertainty and complexity (Morgan, et al., 2006).

These two aspects impact and generate stress for small and young businesses. In addition, staying in such competitive context needs some entrepreneurial abilities (Lee \& Pennings, 2005). Moreover, features of corporate entrepreneurial behavior also are remarkably impacted by nature of their relations with context (Minguzzi \& Passaro , 2001). In addition, a lot of companies currently are trying to compete within international market and to participate in some corporate entrepreneurship (Ireland \& Webb, 2007). Thus, it is important to understand and study the contextual components within the individual organization and entrepreneurship (Wang \& Zhang, 2009).

Obtaining the reliable outcomes in entrepreneurship investigations needs a comprehensive method to forming factors of entrepreneurial procedures such as individual, environmental as well as organizational procedures (Adams \& Sykes, 2003); (Audretsch \& Keilbach, 2003). The research of entrepreneurship in organizational level or the corporate entrepreneurship (CE) has become significantly important in managerial researches (Dess, et al., 2003). The CE could be described as an entrepreneurial behavior demonstrated by existing firms. Such process might lead to generating some new ventures for example "corporate venturing" or in case of organizational revitalization as well as "strategic renewal". Both of these procedures include innovation that is the presentation of new concepts to marketplace (Yilmaz, et al., 2005).

$\mathrm{CE}$ is assumed as a helpful method for improvement and revitalization of performance. In case of emerging economies which are adapting their markets to standards in developed markets, CE might be 
considered as a critical property for profitability and also growth of existing organizations (Antoncic \& Hisrich, 2000) ( Antoncic \& Hisrich, 2001); (Khanna \& Palepu, 2011); (Banerjee , 2003). Also CE might improve their capability to understand and get the opportunities over their competitors (Shane \& Venkataraman, 2000); (Ahlstrom, et al., 2007).

The emerging economies are currently a main economic force globally and entrepreneurship has a critical role in this procedure (Bruton, et al., 2008). In particular, organizations in Russia, Brazil, India, South Africa and China (BRICS) should re-test the traditional methods of conducting business and provide entrepreneurial mindset (You \& Liu, 2008), due to they are growing although having competitive and hostile contexts (Weeks, 2008). The strategic corporate entrepreneurship (SCE) suggests a suitable strategy for organizations to reconfigure their sources in new ways and also exploit and understand opportunities (Irland \& Webb, 2002); (Kyrgidou \& Hughes, 2010). Hence, the corporate entrepreneurship is critical in competitive markets these days. A lot of attempts have been done to understand those variables which define the commitment of a corporation to the corporate entrepreneurship (Lumpkin \& Dess, 1996); (Zahra, et al., 2000).

These days, entrepreneurship in small and medium enterprises (SMEs) is a good strategy to deal with transition period and is suggested for both developed and developing countries. Of almost 350 million industrial commercial units with more than 2 billion employees currently operating globally, beyond 90 percent of them are small and medium enterprises (Fakour \& Ansari, 2009). Such small and medium businesses can become universal through their own products and services and by benefiting from presented patterns and strategies (Lee \& Tsang, 2001).
The most important aspects of a competitive economy are generating private sectors, improving the entrepreneurship as well as expanding small and medium businesses. During recent years, a lot of changes within the business industries took place. The universal business context is moving toward the developing nations that can lead to high globalization as well as integration. Such modifications explain that small and medium businesses have a critical role in promoting and also altering the economies. The development and growth of economies in various societies across the world are related to new businesses so they are being developed and created according to them.

In this regard, the entrepreneurs in every single society have an important role to develop entrepreneurship and businesses and it can be a vital tool to understand opportunities and use them to confront with challenges for example unemployment, lack of dynamic and creative employees, low quality services and products, efficiency, competition and economy recession (Landstrom, 2005).

Therefore, rapid changes across the world in terms of technical and scientific areas and also existed socio-economic issues, reduction in underground resources and also unemployment and poverty made the researchers and also policy makers focus more on development of small and medium businesses. Due to crucial role of such businesses within social and economic growth and also development of nations and particular emphasize of policy makers on such issue, it would be critical to begin some fundamental proceeding in order to improve condition of such institutions. These are the places to grow, develop, innovate, entrepreneur and take the risks that are the bases for stable growth and moving toward organizational improvement.

A lot of small and medium businesses suggest new opportunities to develop 
competitive advantages. Besides, such businesses are the main part of development in technology and provide advanced and complex requirements in each country (Hurmelinna-Laukkanen, et al., 2008).

In recent years, Iran attempted to support SMEs in order to contribute the economic development of this country (Kamyabi \& Devi, 2010) (Arasti, et al., 2014). Due to CE can improve the performance of SMEs so it is important to identify the influential factors on CE. The conducted studies by (Hornsby, et al., 2009), (Turró, et al., 2014) and (Armesh , et al., 2014) revealed that in order to improve $\mathrm{CE}$ we should focus on organizational factors.

Organizational factors consist of management support, values, organizational culture, work independence, formal control, environment monitoring, and organizational communication. According to the critical role of SMEs in economic growth of Iran, it is necessary to investigate the role of organizational factors in improvement of $\mathrm{CE}$. Role of each organizational factor to improve the $\mathrm{CE}$ creates some level of ambiguity. Hence, this study aims to find how organizational factors can affect corporate entrepreneurship in Iranian SMEs.

\section{Literature Review}

\subsection{Entrepreneurship}

The Corporate Entrepreneurship concept (known as Entrepreneurship Activity or Organizational Entrepreneurship) has been investigated for more than thirty years. Some scholars for example (Peterson, 1971), (Pinchot, 2002. III (1985)) and (Hanan, 1976) were some of these first movers that suggested many definitions for CE. In addition, (Sathe, 1985) explained Organizational Renewal Process. The corporate entrepreneurship in fact both motivates and stimulates innovation inside companies which are familiar with entrepreneurship concept. So it needs improving their activities in entrepreneurship in an organization. The entrepreneurship is not just for generating new business however to do other innovation acts and methods for instance developing the services and products, administrative techniques, new technology as well as business strategies. The three highly identified entrepreneurship dimensions at organizational level are as 1) New Business Venture, 2) Innovation of services/products, and also 3) Innovation of Processes.

The first dimension includes both semi and fully independent enterprises or units which are identified as Formative Entrepreneurship (Schollhammer, 1981) (Schollhammer, 1982). Developing the new and independent enterprises (MacMillan, 1984) domestic risk activity (Hisrich, 1984), developing the independent businesses (Vesper, 1984), the entrepreneurship activity (Guth \& Ginsberg, 1990), new spectrum (Kanter, 1991) as well as enterprise risk activity (Sharma, 1999). The other dimensions of $\mathrm{CE}$ emphasize on technology development. According to previous studies of various scholars, the $\mathrm{CE}$ includes abundant products within leading technologies (Covin \& Slevin , 1991), offering new products and promoting their performance and also techniques of manufacturing (Schollhammer, 1982), development and advancement of product level and relevant services to technology and methods (Knight , 1997).

Other scholars asserted that the CE includes many entrepreneurship methods that need organizational approval and should be compatible with all of the resources in order to conduct such innovative acts (Schollhammer, 1982); (Burgelman, 1983); (Kanter, 1985) (Alterowitz, 1988); (Jennings \& Seaman , 1990). According to (Damanpour, 1991), corporate entrepreneurship is a general concept including manufacturing, developing and establishing new behaviors and ideas. An 
innovation might as some new services or products, a plan or an administrative system consisting organizational members. Moreover, CE includes improving and renewal of organization's capacity to achieve and advance innovative and skill capabilities. Generally, entrepreneurship is the procedure which attempts to act and innovate progressively. This would be the nature of entrepreneurship (Bygrave, 1991). A lot of advancements in entrepreneurship researches are initiated from entrepreneurship analysis as a procedure and so an organizational basis which is dependent. Hence, the question is that how entrepreneurship acts are impacted by the organizational decisions. Time limitations, reasoning or entrepreneurship activity type can impact personality as well as preferences of entrepreneurs (Stevenson \& Jarillo, 1990). So, one should pay more specific attention to compatibility among research methodology and entrepreneurship studies results.

Previous studies on CE classified two corporate entrepreneurship groups antecedents as: one group points out organization (Hornsby, et al., 2009); (Turró, et al., 2014); (Armesh , et al., 2014)and also the other group refers external context (Armesh , et al., 2014); (Edelman \& YliRenko , 2010); (Zahra, 1993) of firms. However, this study specifically focuses on organizational factors.

\subsection{CE's dimensions}

The corporate entrepreneurship studies usually emphasize on two aspects: the external context of an organization and internal factors at organizational-level. Also entrepreneurship could be grouped as four aspects including (1) Innovation, (2) New Business Venturing, (3) Proactivity and (4) Self-Renewal.

\subsection{New business ventures}

One of the most important key features of entrepreneurship is new business ventures due to the lead to new business development in an organization. This could be achieved via redefinition of products and services of a company or through creating new markets. In big corporations, it also covers developing more formal semi-autonomous or autonomous units, corporate start-ups, internal ventures, developing the autonomous business unit and also new streams. In all of the organizations in any size, such new dimension of business venture means generating new businesses in an organization without considering its autonomy level ( Antoncic \& Hisrich, 2001) (Antoncic \& Hisrich, 2004).

\subsection{Innovation}

Innovation in fact means the development of services or products with a focus on innovation technological improvement both. The entrepreneurship includes product enhancement, new product development as well as new methods and processes of production. (Covin \& Slevin , 1991) studies the entrepreneurship posture which demonstrated regularity and also extensiveness of products innovation and also technological leadership inclination. Also in 1997, Knight asserted that product development, services, technologies and methods in production process are aspects of organizational innovation (Knight ， 1997). Zahra described technological entrepreneurship and product innovation as innovative dimensions of manufacturing ( Antoncic \& Hisrich, 2001) (Antoncic \& Hisrich, 2004). 


\subsection{Self-Renewal}

Self-renewal aspect shows the transformation of companies through renewing the core ideas by which they will develop. It includes both organizational and strategic transformation and defines again the concept of a business, establishes organization and also introduces remarkable innovative changes in a system ( Antoncic \& Hisrich, 2001) (Antoncic \& Hisrich, 2004).

\subsection{Pro-activeness}

The last part is proactivity which is the aggressive posturing into other rivals. A proactive organization takes risk through experiments; it will take the initiative, is aggressive and also bold to pursue the opportunities. The proactive concept means the degree to which companies try to lead instead of following their rivals. This can be applied to critical business areas such as offering new services and products, administrative techniques and operating technologies. The proactivity includes risk and initiative taking as well as competitive aggressiveness which are shown in activities and orientations of top managers ( Antoncic $\&$ Hisrich, 2001) (Antoncic \& Hisrich, 2004).

\subsection{3. Relationship between organizational factors and $\mathrm{CE}$}

\subsubsection{Management Support and CE}

Studies reveal that internal factors of an organization motivate individuals to organize their organizational performance and entrepreneurial activity (Zahra, 2007). According to (Hornsby, et al., 1990), different internal context dimensions such as management support for $\mathrm{CE}$, reinforcing programs and work discretion, time access and the other sources, improve the organizational scope overall (Hornsby, et al., 1990) (Kuratko, 1990). The five-dimension structure is a brief explanation of internal factors of an organization that motivates middle managers to hasten entrepreneurship attempts in organizations (Hornsby, et al., 2002). The study conducted by (Gantsho, 2006) on SMEs in Europe in manufacturing provided another aspect to the existing five dimensions and evaluated the organizational innovation within entrepreneurial organizations.

In addition, (Chen \& Cangahuala, 2010), suggested that organizational communication and commitment have a remarkable relationship with job performance and CE. Thus, it seems that corporate entrepreneurship can make balance between organization and commitment which leads to improved performance. Besides, both management and organizational support are two positive factors motivating commitment ( Antoncic \& Hisrich, 2001). Also (Hitt, et al., 2011) suggested empirical proof demonstrating the top management status in supporting as well as controlling the activities of team members in line with the production process (Hitt, et al., 2001) and also innovation (Soonhee, 2009). Moreover, (Cooper, et al., 2004) mentioned that ideas of top managers is significant in defining the time interval in presenting the new products and services (Cooper, et al., 2004). Applying the meta-analysis, Henard and Zimanski attempted to describe the factors which impact capability of organizations in order to present new products (Henard \& Szymanski, 2001). In current research, the positive relationship among the support factors of top management and entrepreneurial activity of presenting new products was verified. In addition, the higher management role was explained to introduce a future landscape, promotion of a specific product concept, allowing for projects initiation which introduces new products and also bringing critical resources (Haynie, et al., 2010). Hence, management support has high potential to affect CE. So, the first hypothesis will be as follow: 
H1: management support affects CE significantly and positively

\subsubsection{Organizational Values and $C E$}

The organizational values are key values of organizational beliefs that lead to growth of people in teams. The main values in an organization are the guiding rules and do not require any justification and are important and valued intrinsically for employees (Terziovski, 2010). The key organizational values could be the foundations for policy making within the organizations relevant to organizational entrepreneurship. Organization uses such values in order to describe daily behavior of its employees and also decision makings in organization. It is more helpful that organizations consider their core values while developing plans for long term and when assessing organizational performance, make decision based on such values.

These values will encourage the staff in hardship and if not, so they are not core values. These core values are daily slogans that make god feelings to employees and the organizational values are known as ethical aspects of organization (Tabarsa, 2011).

Those organizations which nurture organizational values and structures motivating entrepreneurial activities are probably growing more compared to those companies that do not. Quality and open communication, using the formal monitoring, regular environment control, organizational support, managerial support and values generally, help the organization to improve entrepreneurial qualities. The entrepreneurial companies participate in new business ventures and are more innovative; they usually renew themselves and also are highly proactive regarding their endeavors. Within the transition economies that are improving their economic position toward developed standards economically and where growth might not be the key goal, even the entrepreneurship is more necessary for profitability and growth of their existing companies ( Antoncic \& Hisrich, 2001) (Antoncic \& Hisrich, 2004).

The organizational values are considered as critical entrepreneurship drivers. Guth and Ginsberg asserted that the entrepreneurial behavior inside companies is significantly dependent on values, characteristics, visions and beliefs of strategic leaders in that organization (Guth \& Ginsberg, 1990). (Zahra, 1991) mentioned that there is a positive relationship between organizational values and corporate entrepreneurship which are individual centered and those values which are competition centered. So, it is value-based and emotional commitment which increases innovation in organizations (Kanter, 1985).

Organizational Values are viewed as important drivers of entrepreneurship. (Guth \& Ginsberg, 1990) Hence, the second hypothesis can be written as follow:

$\mathrm{H} 2$ : Organizational values affect $\mathrm{CE}$ significantly and positively

\subsubsection{Organizational Culture and CE}

The organizational culture reveals a group of norms, beliefs and values that is mutual between all of the employees in organizations. One of the features of entrepreneurial organizations is that they have a flexible entrepreneurship or culture. It shows that via flexibility and based strategic perspective; the external context would be focused and will attempt to meet the demands of customers. In such culture, beliefs and norms which are accepted can make it possible to understand environmental variables and so interpret them and take the necessary actions according to them or demonstrate a proper behavior. This kind of organizations needs to respond quickly to new designs and also to be able to develop and restructure a group of new actions regarding new tasks (Kuratko, 2004). Those 
companies that do not have flexible culture and structure to generate alliance and collaboration will encounter with chaos while there are crises but those companies which can forecast the connections, in particular flexible and informal connections in their structures, will generate effective and positive variable for more creativity and innovation inside the organization in order to improve organizational performance. Reinforcing and also creating the entrepreneurial behaviors and values and viewpoints in general are known as business culture and is one of the core governmental strategies components to improve entrepreneurship. Often the goal is followed in forms of promotional, persuasive and educational plans and policies in all social levels.

Due to its delicate and complex nature, more than other aspects of entrepreneurship strategies development, requires contribution of all individuals and various social levels by means of collaboration; the probability of institutionalizing various cultures and positive hidden values within the subcultures could be done (García-Morales, 2012). The cultural environment as one of the infrastructure element or even the basis of other needed infrastructures regarding entrepreneurship, requires to have big evolutions in rights, beliefs, customs and ethics of people. Significantly, the organizational culture effects entrepreneurship. The traditional organization's culture support decision making which is conservative and in addition would be according to hierarchical method. In general, organizational entrepreneurial culture is flexible that can support innovation and change, entrepreneurship, organizational learning, risk taking, teamwork, providence, mutual trust and honesty, enlivening work with delight and excitement, customer orientation and competition.

The main role of this culture in forming and motivating the entrepreneurial activities is an issue which attracted many scholars comparing to the other organizational aspects impacting the CE (Sadler, 2000), (Zahra, 2005); (Darroch, 2005). The behavioral features of entrepreneurial individuals are the entrepreneurial context functions conforming to place and time (Gantsho, 2006).

H3: Work independency \& empowerment affect CE significantly and positively

\subsubsection{Work independency \& empowerment and CE}

The employee's empowerment and work independency is one of the critical methods for improving the employee's efficiency and maximum use of group and individual capabilities and skills in line with organizational goals and organizational performance. We can note that the empowerment is one the strategies for growth and development of an organization. The organizations encounter with many pressures due to a lot of factors including rising competition globally, quick changes, need for after sales services and quality and also limited sources.

Based on the experience in many years, it was concluded globally that if any organization is going to be a leader and entrepreneurial in both economy and work in order to survive such competition, it must have creative, professional and encouraged human resources. Human resources in fact form the basis of real organizational wealth. There is a significant relationship between organizational efficiency and human resources (Gresov \& Drazin, 2007). Using the potential capabilities of the human resources is assumed as a key benefit for organizational entrepreneurship. In terms of individual efficiency, an organization employs all of its potential and skills for advancement and via such potential strengths and effective talents will generate individual advancement in organization. 
Thus, in order to have organizational entrepreneurship, the proper management of such resources is necessary. Here, HRM scholars and professions have emphasized advancement, growth and development of capabilities in employees during past years known as empowerment and independency. Since the organization will stand against challenges and assume the stable improvement as its primary objective so there is a necessity for more support and commitment of employees and making them to participate in various tasks. Empowerment and work independency are effective and new methods for improving the organizational efficiency in line with entrepreneurship via using skills and abilities of employees (Katsikea, 2011).

Followed by above discussion, the third hypothesis can be developed as follow:

H4: Work independency \& empowerment affect CE significantly and positively

\subsubsection{Formal Control and CE}

Due to there is a significant formality in organizations, there is no authority for employees. Tasks are not also flexible and tolerable. Also employees are not able to demonstrate various behaviors. In this regard, since learning is not an important factor to develop plans and organizational performance so the employees are not encouraged to learn. But, in entrepreneurial organizations, flexibility, learning and taking the risks are the main principles.

On the other hand, organizations can be named as entrepreneurial if they are able to take the risks and assign authority for decision making and appropriate judgment to employees and allow them apply their individual creativity to perform tasks. It could be accomplished if the amount of operational standards, instruction and also circulars are reduced as much as possible thus staffs can show their abilities. Here, there exists a negative relationship between formality and organization entrepreneurship (Chiva, 2009). In an entrepreneurial organization in which the power to make decisions is assigned to people and units to plan and develop appropriate actions at the right time, the concept of centralization could be neglected. Referred to creativity, operational and talent or the intellectual ability of experts in such contexts, decentralization can take place.

In addition, other aspects of organizations specifically the technology and size have significant impact on centralization. Larger organizations which have more experienced professionals and also appropriate communicative networks which are suitable for updated technology will result in high decentralization and lower authority. When the staffs have enough knowledge, there would be more authority and better situation for centralization as well (Lumpkin, et al., 2010).

For conclusion, to strengthen the entrepreneurship, an organization should generate an environment full of freedom, flexibility and interactive communication of potential entrepreneurs. This could be understood when satisfaction of employees is optimum and they benefit from having freedom to participate more in individual innovation and occupational viewpoints (Zahra, 2007). The findings revealed that formal control can have negative or positive influence on organizational performance and CE (Antoncic, 2001); (Zahra, 2007). Followed by above discussion, the fifth hypothesis can be developed as follow:

H5: formal control affects CE significantly and positively

\subsubsection{Environmental monitoring and $C E$}

Network shows organization as being a complicated structure of relationships through which many organizations are existed. The main issue for understanding this network is 
presenting a specific border among the environment and organization. Managers place their organizations at center of this network and so those organizations that interacting with their key competitors and interactively will solve such problem. Thus, managers might neglect the outside information of such border of defined network. A part of this information could be remarkably valued. Next, managers are interested to guide the information into central part of this model that is the top management and organization (Haynie, et al., 2010). Studying the relationships in a network inside the organization can contribute managers to realize the dependency/authority relationship among organization and other network players for the better organizational performance.

The organizational dependency is not according to a single way or dependency rather it is complex set of dependencies among environmental factors and an organization inside the inter-organizational network (Villiers-Scheepers, 2012). The solution for such competitive action practically is to rank resources according to their vitality and availability. The vitality refers to estimation of importance level for specific resources. The critical resources are those that organizations could not perform without them. The necessary and rare resources suggest the strongest for role of the entrepreneurs inside a network. The environmental monitoring emphasizes on alteration of organizational context in a way that it omits harmful and improper elements from organizational environment and improves the helpful and effective variables on both organizational efficiency and process. According to method of environmental monitoring and its appropriate conduction, there can be an optimum entrepreneurship establishment.

By review the extant research, we can conclude that environmental monitoring has potential to affect CE. So, next hypothesis will be as follow:

H6: Environment monitoring affects CE significantly and positively

\subsubsection{Organizational Communication (OC) and CE}

Organizational communication is an interindividual process that considers the relationships of employees inside the organization. The communication among two or more individuals will be developed via physical proximity and according to its novel characteristics, an indicator of investigations on communication will be focused (Morris \& Kuratko, 2002). All of the companies maybe assumed as some goal-oriented communities in which individuals are communicating with others due to many reasons. But, the key motivator for cooperation is that goals of organization and employees could not be achieved through solo performance rather through cooperation and teamwork. Hence, communication in organizations is considered as one of the core variables to achieve organizational goals and via such process the exchange of information could be done and so organizations can use this information to get the objectives (Danneels, 2007).

This relationship among the organizational interaction, performance and commitment interested the scholars for a long time. A lot of attention was given to the relationship between organizational interaction and organizational performance and corporate entrepreneurship.

The employees' commitment could be known as one of the key factors to improve the organizational performance. In many companies, high level of stress results in less satisfaction and also less organizational commitment (Elangovan, 2001). It is mentioned that more organizational communication leads to more employee commitment. This can result in more performance too (Chen \& Cangahuala, 2010). 
In 2010, Chen and Cangahuala investigated the relationship between job performance, communication and organizational commitment (Chen \& Cangahuala, 2010). The results revealed that there are positive relationships among job performance, communication and organizational commitment. These results suggested that organizations empower their communication processes and channels for empowering their job performance and organizational commitment of their accounting professionals.

As noted by Zahra, communication is necessary since novel ideas could be more conveniently presented to an organization and staffs could become familiar with such new trends within different fields (Zahra, 1991). In addition, fluid and clarified communication is important between different interdisciplinary sectors since usually idea creation needs participation of various organizational departments for example HRM, Finance and Operations. Moreover, according to (Zahra, et al., 2009) asserted that through looking for consensus and having meetings regularly, staffs will have a chance to contribute. This can be a useful mutual platform between organizational goals and intrinsic motivation of employees that should be developed for generating the $\mathrm{CE}$ inside the organization (Kenney \& Mujtaba, 2007). If there is no employee involvement so there is low levels of intrinsic motivation, thus communication is remarkably relevant to corporate entrepreneurship. For instilling a supportive internal context of $\mathrm{CE}$, the quantity and quality of communication are important (Zahra, 1991). The mentioned results above have been confirmed by (Antoncic, 2007) (Antoncic, 2001); ( Antoncic \& Hisrich, 2001) (Antoncic \& Hisrich, 2000).Even though the studies by Antoncic cover the entrepreneurship but his definition of this concept is as same as CE generally. So, the seventh hypothesis of the study can be developed as follow:

H7: Organizational commitment affects CE significantly and positively

\section{Methodology and Results}

As mentioned above organizational factors have potential to affect CE. Figure 1 shows the proposed framework of this study achieved from previous research.

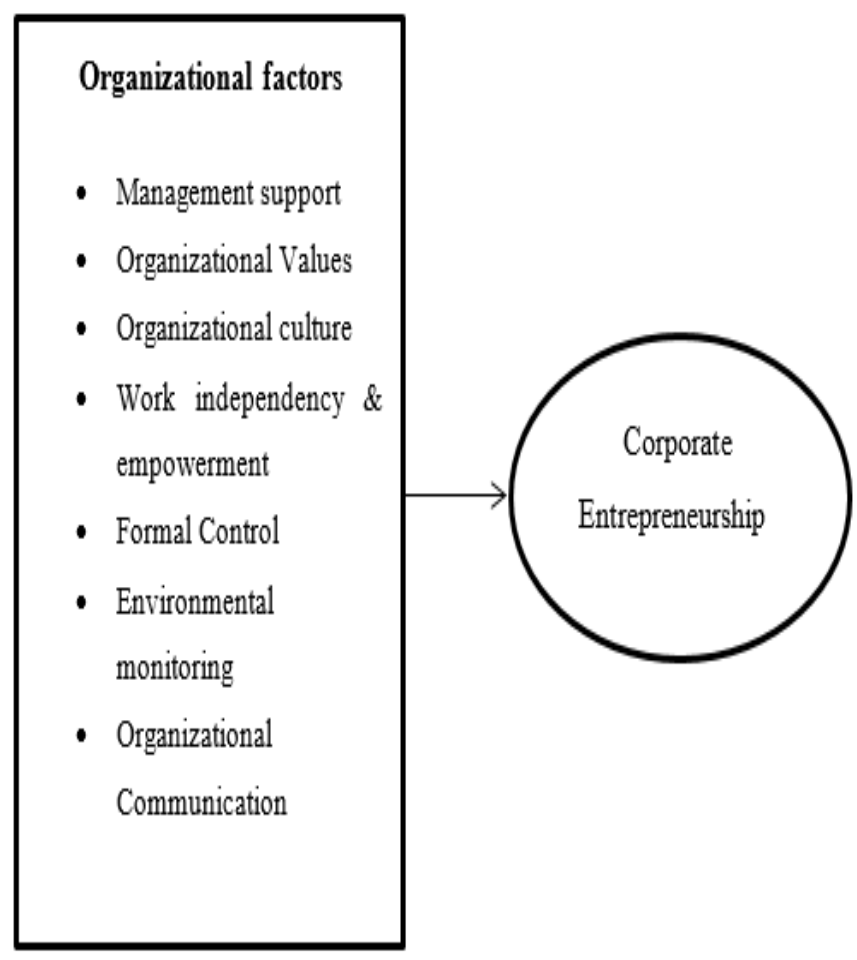

Figure 1: Proposed Framework

This research applied quantitative approach (hypothesis testing) to measure the impact of each environmental factor on CE. For this purpose, it was needed to gather primary data through survey questionnaire. The questionnaire items were adapted from different previous studies. Table 2 demonstrates the references and number of items for each variable.

To measure each item, 5- point Likert scale was applied. The population of this study was all top and middle managers who are working 
in the 50 SMEs in 5 largest provinces of Iran. The population size was 2457 , so the sample size was 265 according to the (Krejcie, 1970 ). So, 280 questionnaires were distributed, but 251 usable questionnaires were received. This number of data is enough to apply multiple regression analysis (Hair, 2010). The needed data was gathered since March 2016 until June 2016. The questionnaire had two parts. The first part was concentrated on demographic questions including gender, experience, number of employees, and qualification. The second part referred to the measurement of independent and dependent variables. Corporate entrepreneurship was measured by 8 items which are obtained from previous studies (they are presented in Table 2). For each independent variable 5 items were adopted from extant research (as shown in Table 2). Besides, the questionnaire is presented in Appendix.

After gathering data through Likert Scale, the mean of answers were calculated. The obtained results help to apply different statistical analysis such as Pearson correlation, and multiple regression analysis. Pearson correlation test shows the relationship between two variables regardless impact of one of them on another one. Multiple regression analysis usually is applied to measure the impact of one or more independent variables on dependent variables. in other words, this method shows that for every unit increase variation in independent variable how many unit increase dependent variable will have. There are two main indicators in multiple regression analysis including R-Square and VIF. Rsquare shows that how many percent of variation of dependent variable is dependent to highlighted independent variable. VIF is an indicator to measure multicoliniearity of independent variables. When VIF is greater than 5 , the researcher should revise the chosen independent variables.
Referring to the Table 2, the results of reliability test shows that all of the variables have acceptable internal consistencies since all estimate devalues are greater than .7 according to the (Nunnally, 1978)

Table 2: Research Items and Reliability Test

\begin{tabular}{|c|c|c|c|}
\hline Variables & No of items & References & $\begin{array}{l}\text { Cronbach's } \\
\text { Alpha }\end{array}$ \\
\hline CE & 8 & $\begin{array}{l}\text { (Armesh, et al., 2014); (Zahra, 2007); ( } \\
\text { Antoncic \& Hisrich, 2001) (Antoncic \& Hisrich, } \\
\text { 2004); (Lvo M \& Covin, 2005) }\end{array}$ & .801 \\
\hline Management support & 5 & $\begin{array}{l}\text { (Armesh, et al., 2014); (Zahra, 2007) (Zahra, } \\
\text { 2010); (Hornsoy, et al., 2002) }\end{array}$ & .774 \\
\hline Organizational Values & 5 & $\begin{array}{l}\text { (Armesh, et al., 2014); (Zahra, 2007) (Zahra, } \\
\text { 2010)(Hornsby, et al., 2002) }\end{array}$ & .771 \\
\hline Organizational culture & 5 & $\begin{array}{l}\text { (Armesh, et al., 2014); (Garcia-Morales, 2012); } \\
\text { (Zahra, 2007); (Zahra, 2010) }\end{array}$ & .767 \\
\hline $\begin{array}{l}\text { Work independency \& } \\
\text { empowerment }\end{array}$ & 5 & (Armesh, et al., 2014); (Jogaratnam, 2006) & .821 \\
\hline Formal Control & 5 & $\begin{array}{l}\text { (Armesh, et al., 2014); (Jogaratnam, 2006), } \\
\text { (Bulut \& Yilmaz, 2008) }\end{array}$ & .832 \\
\hline Environmental monitoring & 5 & (Armesh , et al., 2014); (Haynie, et al., 2010) & .791 \\
\hline $\begin{array}{l}\text { Organizational } \\
\text { Communication }\end{array}$ & 5 & $\begin{array}{l}\text { (Armesh, et al., 2014); (Morris \& Kuratko, } \\
\text { 2002); (Antoncic, 2007); (Antoncic \& Hisrich, } \\
\text { 2001) (Antoncic \& Hisrich, 2004) }\end{array}$ & .759 \\
\hline
\end{tabular}

The first part of questionnaire referred to demographic questions. Table 3 shows the results of demographics. 


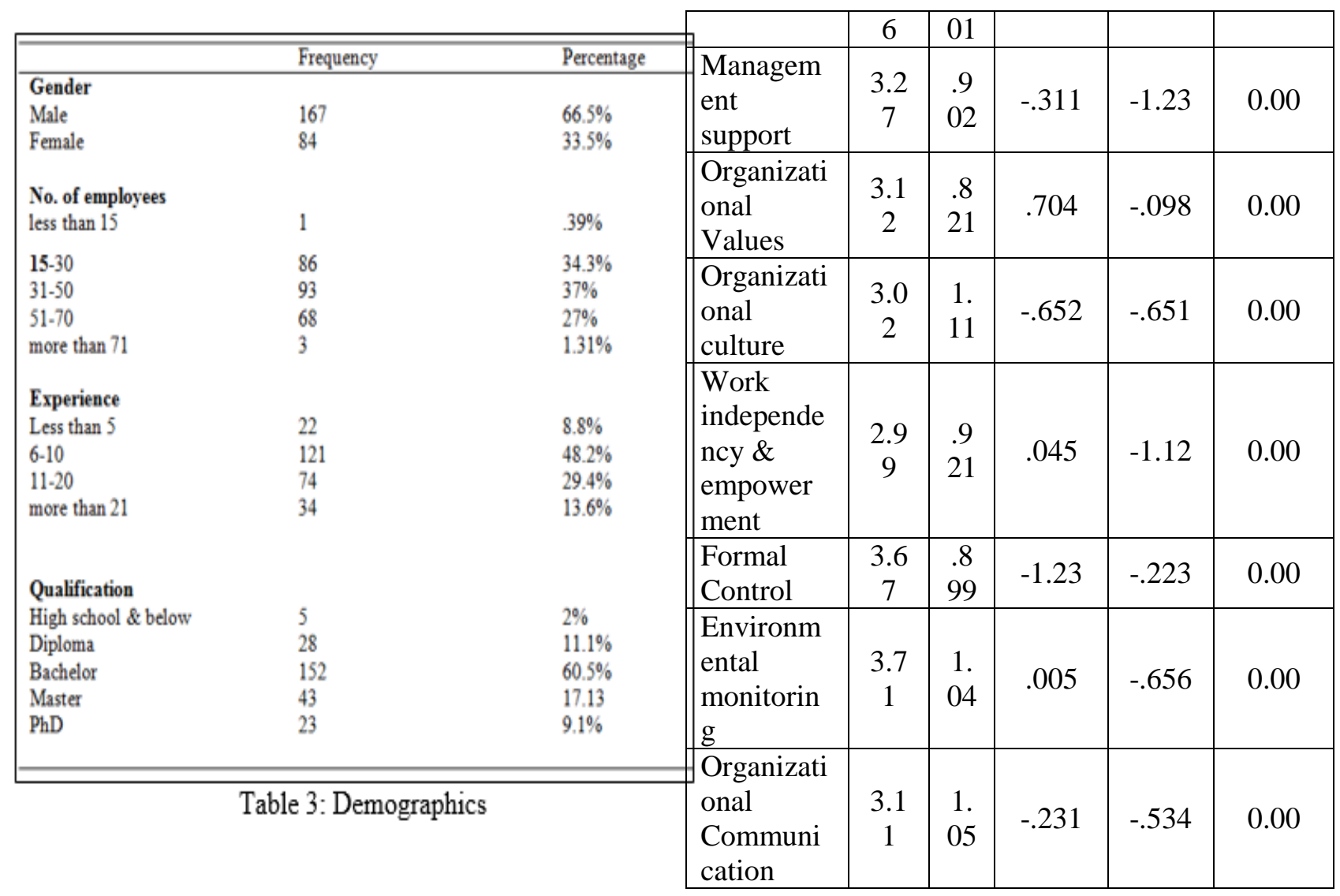

According to the table 3, 66.5\% of respondnets are male while $33.5 \%$ are female. Besides, the highest frequency of number of employees refers to the group 31-50. Most of the respondnets belong to the group experience 6-10. Out of 251 respondnets, 152 have bachelor degree (highest frequency) while the lowest frequency (5) referred to the first group which have high school or below degrees.

Next statistical analysis is mean analysis. Table 4 shows the results of mean analysis based on the four main central indicators mean, standard deviasion, skewness and kurtosis.

Table 4: descriptive Analysis

\begin{tabular}{|l|c|c|c|c|c|}
\hline Vraiables & $\begin{array}{c}\text { Me } \\
\text { an }\end{array}$ & $\begin{array}{c}\text { S } \\
\text { D }\end{array}$ & $\begin{array}{c}\text { Skew } \\
\text { ness }\end{array}$ & $\begin{array}{c}\text { Kurt } \\
\text { osis }\end{array}$ & $\begin{array}{c}\text { Norma } \\
\text { lity } \\
\text { test } \\
\text { (P- } \\
\text { value) }\end{array}$ \\
\hline CE & 3.4 & 1. & -.291 & -.767 & 0.00 \\
\hline
\end{tabular}

Reffering to the table4, all estimated values for mean vary between 2.99 (work independnecy and empowerment) and 3.71 (environemntal monitoring). The negative signs of skewness asserted that the peak of the frequency chart is centralized to the right direction while the positive signes shows left direction. All of the estimated values for kurtosis are negative, so all of them have flat distribution.

Besides, table 4 shows the results of normally test based on the Kolmogrov -Smirnov test. All of the p-values are less than .05, so none of the variables is normally distributed. Nonetheless, according to the central limit theorem we can assume them normally distributed because sample size is greater than 30. Table 5 shows the results of Pearson correlation test.

*. Correlation is significant at the 0.05 level (2-tailed). 
**. Correlation is significant at the 0.01 level (2-tailed).
As shown in Table 5, all of the variables are correlated significantly and positively because all of the estimated p-values are less than .05. The highest relationship with $\mathrm{CE}$ refers to work independency and empowerment while the lowest relationship belongs to organizational values. However, there is no high relationship between each pairs of independent variables. The next statistical analysis refers to multiple regression analysis (See table 6).

Table 5: Pearson Correlaticus Test

\begin{tabular}{|c|c|c|c|c|c|c|c|c|c|}
\hline & & $\mathrm{CE}$ & $\begin{array}{c}\text { Managemen } \\
\text { t Support }\end{array}$ & Values & Culture & $\begin{array}{c}\text { Independency \& } \\
\text { enpowernent }\end{array}$ & $\begin{array}{l}\text { Fcrmal } \\
\text { Centrol }\end{array}$ & $\begin{array}{c}\text { Environmental } \\
\text { nonitoring }\end{array}$ & $\begin{array}{l}\text { Organizaticnal } \\
\text { conmunication }\end{array}$ \\
\hline$C E$ & $\begin{array}{l}\text { Pearson Correlation } \\
\text { Sig. (2-tanled) } \\
\mathrm{N}\end{array}$ & $\begin{array}{l}1 \\
251\end{array}$ & & & & & & & \\
\hline Managzment Support & $\begin{array}{l}\text { Pearson Correlation } \\
\text { Sig. (2-tsiled) } \\
\text { N }\end{array}$ & $\begin{array}{l}.467^{4 *} \\
.000 \\
251\end{array}$ & $\begin{array}{l}1 \\
251\end{array}$ & & & & & & \\
\hline Values & $\begin{array}{l}\text { Pearson Correlation } \\
\text { Sig (D-twileri) } \\
\mathrm{N}\end{array}$ & $\begin{array}{l}409^{4} \\
000 \\
251\end{array}$ & $\begin{array}{l}.273^{+4} \\
000 \\
251\end{array}$ & $\begin{array}{l}1 \\
251\end{array}$ & & & & & \\
\hline Culture & $\begin{array}{l}\text { Pearson Correlation } \\
\text { Sig. (2-twiled) } \\
\mathrm{N}\end{array}$ & $\begin{array}{l}.476^{-1} \\
.000 \\
251\end{array}$ & $\begin{array}{l}.330^{\circ} \\
.000 \\
251\end{array}$ & $\begin{array}{l}.187^{-1} \\
.000 \\
251\end{array}$ & $\begin{array}{l}1 \\
251\end{array}$ & & & & \\
\hline $\begin{array}{l}\text { Indepeadency \& } \\
\text { empowerment }\end{array}$ & $\begin{array}{l}\text { Pearson Correlation } \\
\text { Sig. (2-tiiled) } \\
\text { N }\end{array}$ & $\begin{array}{l}576^{21} \\
.001 \\
251\end{array}$ & $\begin{array}{l}.207^{\prime \prime} \\
.000 \\
251\end{array}$ & $\begin{array}{l}.156^{\prime *} \\
.002 \\
231\end{array}$ & $\begin{array}{l}.176^{\circ} \\
.000 \\
251\end{array}$ & $\begin{array}{l}1 \\
2 S \mathrm{~L}\end{array}$ & & & \\
\hline Formal Control & $\begin{array}{l}\text { Pearson Correlation } \\
\text { Sig. (2-tiled) } \\
\text { N }\end{array}$ & $\begin{array}{l}.432^{* 1} \\
.000 \\
251\end{array}$ & $\begin{array}{l}.291^{\prime \prime} \\
.000 \\
251\end{array}$ & $\begin{array}{l}226^{* 1} \\
.000 \\
251\end{array}$ & $\begin{array}{l}.276^{+1} \\
.000 \\
251\end{array}$ & $\begin{array}{l}.211^{\prime \prime} \\
.0<0 \\
25 \mathrm{t}\end{array}$ & $\begin{array}{l}1 \\
251\end{array}$ & & \\
\hline Enviroumental monitori & $\begin{array}{l}\text { Pearson Correlation } \\
\text { Sig. (2-twiled) } \\
\mathrm{N}\end{array}$ & $\begin{array}{l}.526^{*} \\
.000 \\
251\end{array}$ & $\begin{array}{l}.234^{\prime \prime} \\
.000 \\
251\end{array}$ & $\begin{array}{l}.184^{* *} \\
.000 \\
251\end{array}$ & $\begin{array}{l}.201^{*} \\
.000 \\
251\end{array}$ & $\begin{array}{l}.128^{\prime} \\
.012 \\
251\end{array}$ & $\begin{array}{l}.270^{\prime \prime} \\
.000 \\
251\end{array}$ & $\begin{array}{l}1 \\
2<1\end{array}$ & \\
\hline $\begin{array}{l}\text { Organizational } \\
\text { communicatica }\end{array}$ & $\begin{array}{l}\text { Pearson Correlation } \\
\text { Sig. (2-tailed) } \\
\text { N }\end{array}$ & $\begin{array}{l}.460^{\prime \prime} \\
.003 \\
251\end{array}$ & $\begin{array}{l}.166^{\prime \prime} \\
.001 \\
251\end{array}$ & $\begin{array}{l}214^{* *} \\
-000 \\
251\end{array}$ & $\begin{array}{l}.272^{*} \\
.000 \\
251\end{array}$ & $\begin{array}{l}.223^{\prime \prime} \\
.0 \times 0 \\
251\end{array}$ & $\begin{array}{l}.179^{\prime \prime} \\
.000 \\
251\end{array}$ & $\begin{array}{l}.231^{*} \\
.050 \\
251\end{array}$ & $\begin{array}{l}1 \\
251\end{array}$ \\
\hline
\end{tabular}


Table 6: Multiple Regression Analysis

\begin{tabular}{|c|c|c|c|c|c|c|c|c|c|c|}
\hline \multicolumn{11}{|c|}{ Model Summary } \\
\hline \multicolumn{2}{|c|}{ Model } & $\mathrm{R}$ & \multicolumn{2}{|c|}{ R Square } & \multicolumn{3}{|c|}{ Adjusted R Square } & \multicolumn{3}{|c|}{ Std. Error of the Estimate } \\
\hline & 1 & $.832^{2}$ & \multicolumn{2}{|c|}{.692} & \multicolumn{3}{|c|}{.683} & \multicolumn{3}{|c|}{.50378} \\
\hline \multicolumn{11}{|c|}{ ANOVAb } \\
\hline \multicolumn{3}{|c|}{ Model } & \multicolumn{2}{|c|}{ Sum of Squares } & df & \multicolumn{2}{|c|}{ Mean Square } & $\mathrm{F}$ & \multicolumn{2}{|c|}{ Sig. } \\
\hline \multirow{3}{*}{1} & \multicolumn{2}{|c|}{ Regression } & \multicolumn{2}{|c|}{138.651} & 7 & \multicolumn{2}{|c|}{19.807} & 78.043 & \multicolumn{2}{|c|}{$.000^{2}$} \\
\hline & \multicolumn{2}{|c|}{ Residual } & \multicolumn{2}{|c|}{61.673} & 243 & \multirow{2}{*}{\multicolumn{2}{|c|}{.254}} & & & \\
\hline & Tota & & & 0.324 & 250 & & & & & \\
\hline \multicolumn{11}{|c|}{ Coefficients $^{2}$} \\
\hline \multirow{2}{*}{\multicolumn{3}{|c|}{ Model }} & \multicolumn{2}{|c|}{$\begin{array}{l}\text { Unstandardized } \\
\text { Coefficients }\end{array}$} & \multirow{2}{*}{\multicolumn{2}{|c|}{$\begin{array}{c}\begin{array}{c}\text { Standardized } \\
\text { Coefficients }\end{array} \\
\text { Beta }\end{array}$}} & \multirow{2}{*}{$\mathrm{t}$} & \multirow{2}{*}{ Sig. } & \multicolumn{2}{|c|}{$\begin{array}{c}\text { Collinearity } \\
\text { Statistics }\end{array}$} \\
\hline & & & B & Std. Error & & & & & Tolerance & VIF \\
\hline \multirow{8}{*}{1} & \multicolumn{2}{|c|}{ (Constant) } & -.280 & .158 & \multirow{2}{*}{\multicolumn{2}{|c|}{.158}} & -1.773 & .078 & & \\
\hline & $\begin{array}{l}\text { Mana } \\
\text { Suppo }\end{array}$ & nent & .117 & .050 & & & 2.350 & .020 & .279 & 3.587 \\
\hline & Value & & .086 & .043 & \multicolumn{2}{|c|}{.110} & 1.974 & .050 & .409 & 2.445 \\
\hline & \multicolumn{2}{|c|}{ Culture } & .083 & .037 & \multicolumn{2}{|c|}{.118} & 2.244 & .026 & .457 & 2.188 \\
\hline & Form & ontrol & .125 & .053 & .14 & & 2.344 & .020 & .318 & 3.148 \\
\hline & Comr & ication & .179 & .035 & .19 & & 5.195 & .000 & .890 & 1.124 \\
\hline & $\begin{array}{l}\text { Envir } \\
\text { monit }\end{array}$ & $\begin{array}{l}\text { nental } \\
\text { ag }\end{array}$ & .166 & .034 & .19 & & 4.876 & .000 & .814 & 1.229 \\
\hline & $\begin{array}{l}\text { Indep } \\
\text { empo }\end{array}$ & $\begin{array}{l}\text { lency } \\
\text { ment }\end{array}$ & .340 & .030 & .42 & & 11.204 & .000 & .889 & 1.125 \\
\hline
\end{tabular}


According to the results of table $6, \mathrm{R}$ square is equal to .832 that implies 83.2 of variation of $\mathrm{CE}$ can be achieved by independent variables. P-value of ANOVA table equals zero, so at least of the independent variable of this study significantly affects CE. Since all of the values of VIF are less than 5 , it can be concluded that there is no multi-collinearity among independent variables.

By the results of regression analysis, management support has significant impact on CE because the estimated $\mathrm{p}$ - value is less than .05 (.020). The estimated coefficient is equal to .117 , so for every unit increase and growth in the management support, CE will go up .117 units. Therefore, the first hypothesis $\mathrm{H} 1$ is supported by this study.

As shown in table 6, organizational values have significant impact on $\mathrm{CE}$ because the estimated $\mathrm{p}$ - value is not greater than .05 . The estimated coefficient is equal to .086 , so for every unit increase and growth in the organizational values, CE will go up .086 units. Therefore, the second hypothesis $\mathrm{H} 2$ is supported by this study.

By the results of regression analysis, organizational culture has significant impact on CE because the estimated $\mathrm{p}$ - value is less than .05 (.026). The estimated coefficient is equal to .083 , so for every unit increase and growth in the management support, CE will go up .083 units. Therefore, the third hypothesis $\mathrm{H} 3$ is supported by this study.

We are $95 \%$ confident that the impact of work independency and empowerment on CE is significant because the $\mathrm{p}$ - value is equal to zero. Besides, the estimated coefficient is
.340 to Therefore, for every unit increase in work independency and empowerment, CE will grow .340 units. Consequently, the fourth hypothesis $\mathrm{H} 4$ is supported by this study.

We are $95 \%$ confident that the impact of formal control on $\mathrm{CE}$ is significant because the p- value is equal to .020 (less than .05). Besides, the estimated coefficient is .125 to Therefore, for every unit increase in formal, CE will grow .125 units. Consequently, the fifth hypothesis H5 is supported by this study.

We are $95 \%$ confident that the impact of environmental monitoring on $\mathrm{CE}$ is significant because the $\mathrm{p}$ - value is equal to .000 (less than .05). Besides, the estimated coefficient is .166 to Therefore, for every unit increase in environmental monitoring, CE will grow .166 units. Consequently, the sixth hypothesis $\mathrm{H} 6$ is supported by this study.

We are $95 \%$ confident that the impact of organizational communication on $\mathrm{CE}$ is significant because the $\mathrm{p}$ - value is equal to .000 (less than .05). Besides, the estimated coefficient is .179 to Therefore, for every unit increase in organizational communication, CE will grow .179 units. Consequently, the seventh hypothesis $\mathrm{H} 7$ is supported by this study. 
Normal P.P Plot of Regression Standardized Residual

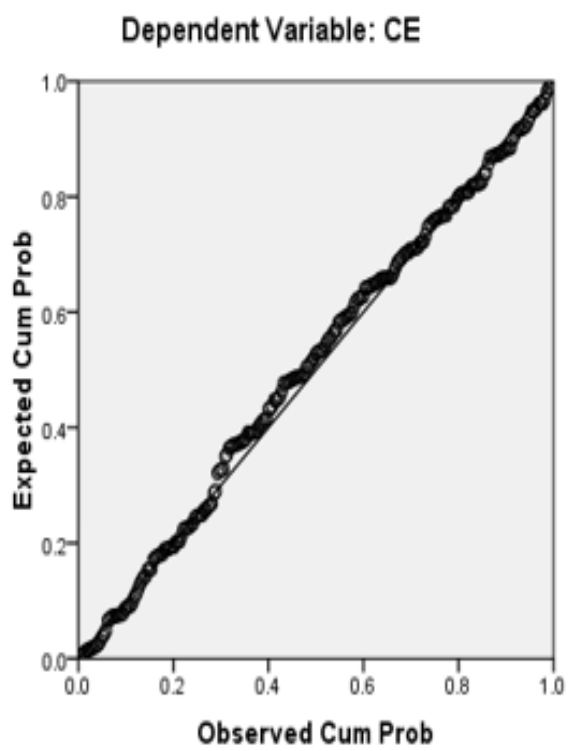

Figure 2: Normal p-plot of regression

Figure 2 shows an acceptable linearity for obtained residuals of the multiple regression analysis. As a result, we can write regression equation as follow:

$\mathrm{CE}=-.280+.117 \quad$ (management support) + .086 (Values) +.083 (Culture) + .125 (Formal Control) +.340 (independency and empowerment) $\quad+.166 \quad$ (environmental monitoring) $+\quad .179$ (Organizational Communication)

\section{Conclusion and Discussion}

Iran like other countries has been trying to improve its economic growth through corporate entrepreneurship of SMEs. There are enough evidences to show that corporate entrepreneurship can be affected by organizational factors. From review of literature review we can conclude that organizational factors consist of management support, organizational values, organizational culture, formal control work independency and empowerment, environmental monitoring, and organizational communication. Hence, this study aimed to find how organizational factors can affect corporate entrepreneurship in Iranian SMEs. The outcome of multiple regression analysis helped to measure the impact of each factor on CE. Besides, these results can be applied to answer the research questions of this study.

\section{What is the relationship between management support and $C E$ in Iranian SMEs?}

By the results of Pearson correlation test, the relationship between management support and $\mathrm{CE}$ is significant and positive. Besides, the results of regression analysis showed that management support has significant impact on $\mathrm{CE}$ because the estimated $\mathrm{p}$ - value is less than .05 (.020). The estimated coefficient is equal to .117 , so for every unit increase and growth in the management support, $\mathrm{CE}$ will go up .117 units. Therefore, the first hypothesis H1 is supported by this study. The obtained results are consistent with extant research conducted by ( Antoncic \& Hisrich, 2001), (Cooper, et al., 2004), and (Hitt, et al., 2011).

\section{What is the relationship between values and CE in Iranian SMEs?}

By the results of Pearson correlation test, the relationship between organizational values and $\mathrm{CE}$ is significant and positive. Organizational values have significant impact on $\mathrm{CE}$ because the estimated $\mathrm{p}$ - value is not greater than .05 . The estimated coefficient is equal to .086 , so for every unit increase and growth in the organizational values, CE will go up .086 units. Therefore, the second hypothesis $\mathrm{H} 2$ is supported by this study. The obtained results are consistent with previous research conducted by (Kanter, 1985), (Zahra, 1991), ( Antoncic \& Hisrich, 2001), (Tabarsa, 2011).

What is the relationship between
organizational culture and $C E$ in Iranian
SMEs? 
By the results of Pearson correlation test, the relationship between organizational culture and $\mathrm{CE}$ is significant and positive. By the results of regression analysis, organizational culture has significant impact on $\mathrm{CE}$ because the estimated p- value is less than .05 (.026). The estimated coefficient is equal to .083 , so for every unit increase and growth in the management support, CE will go up .083 units. Therefore, the third hypothesis $\mathrm{H} 3$ is supported by this study. The obtained results can be considered consistent with previous studies conducted by (García-Morales, 2012), (Gantsho, 2006), (Darroch, 2005), (Zahra, et al., 2009), and (Sadler, 2000).

\section{What is the relationship between work independence \& empowerment and $\mathrm{CE}$ in Iranian SMEs?}

By the results of Pearson correlation test, the relationship between work independence \& empowerment and $\mathrm{CE}$ is significant and positive. $\mathrm{We}$ are $95 \%$ confident that the impact of work independency and empowerment on $\mathrm{CE}$ is significant because the $\mathrm{p}$ - value is equal to zero. Besides, the estimated coefficient is .340 to Therefore, for every unit increase in work independency and empowerment, CE will grow .340 units. Consequently, the fourth hypothesis $\mathrm{H} 4$ is supported by this study. The obtained results are consistent with extant research conducted by (Gresov \& Drazin, 2007) and (Katsikea, 2011).

\section{What is the relationship between formal control and CE in Iranian SMEs?}

By the results of Pearson correlation test, the relationship between work independence \& empowerment and $\mathrm{CE}$ is significant and positive. We are $95 \%$ confident that the impact of formal control on $\mathrm{CE}$ is significant because the p- value is equal to .020 (less than .05). Besides, the estimated coefficient is .125 to Therefore, for every unit increase in formal, CE will grow .125 units. Consequently, the fifth hypothesis H5 is supported by this study. The obtained results are consistent with previous research conducted by (Lumpkin, et al., 2010), (Chiva, 2009), (Zahra, et al., 2009), and ( Antoncic \& Hisrich, 2001).

\section{What is the relationship between environment monitoring and $C E$ in Iranian SMEs?}

By the results of Pearson correlation test, the relationship between organizational values and $\mathrm{CE}$ is significant and positive. We are 95\% confident that the impact of environmental monitoring on $\mathrm{CE}$ is significant because the $\mathrm{p}$ - value is equal to .000 (less than .05). Besides, the estimated coefficient is .166 to Therefore, for every unit increase in environmental monitoring, $\mathrm{CE}$ will grow .166 units. Consequently, the sixth hypothesis $\mathrm{H6}$ is supported by this study. The obtained results are consistent with previous research conducted by (Haynie, et al., 2010) and (Villiers-Scheepers, 2012).

\section{What is the relationship between organizational communication and $C E$ in Iranian SMEs?}

By the results of Pearson correlation test, the relationship between organizational values and $\mathrm{CE}$ is significant and positive. We are $95 \%$ confident that the impact of organizational communication on $\mathrm{CE}$ is significant because the $\mathrm{p}$ - value is equal to .000 (less than .05). Besides, the estimated coefficient is .179 to Therefore, for every unit increase in organizational communication, CE will grow .179 units. Consequently, the seventh hypothesis $\mathrm{H} 7$ is supported by this study. The obtained results are consistent with previous research conducted by (Zahra, 1991), (Kenney \& Mujtaba, 2007), (Antoncic, 2007) (Antoncic, 2001), (Antoncic \& Hisrich, 2000) ( Antoncic \& Hisrich, 2001), and (Morris \& Kuratko, 2002). 


\section{Managerial implications and Future Study}

Followed by above discussion, we can conclude that Iranian SMEs can use the main components of organizational factors to improve CE. According to the results of multiple regression analysis, the highest impact refers to the work independency and empowerment. Hence, Iranian SMEs can increase this factor inside their organizations through transformational leadership (Manafi \& Subramaniam, 2015). It would be better if Iranian SMEs concentrates on their R\&D departments.

Future study can test the proposed framework of this study in other countries and other industries.

\section{References}

Antoncic, B. \& Hisrich, R. D., 2001. Intrapreneurship: Construct refinement and cross-cultural validation. Journal of Business Venturing, 16(5), p. 495-527.

Adams, B. \& Sykes, V., 2003. Performance measures and profitability factors of successful AfricanAmerican entrepreneurs: An exploratory study. Journal of American Academy of Business, 2(3), pp. 418-424.

Ahlstrom, D., Bruton, G. D. \& Yeh, K. S., 2007. Venture capital in China: Past, present, and future. Asia Pacific Journal of Management, 24(3), p. 247-268.

Alterowitz, R. a. Z. J., 1988. New corporate ventures: How to make them work. Wiley.

Antoncic, B., 2007. Intrapreneurship: a comparative structural equation modeling study. Industrial Management \& Data Systems, 107(3), pp. 309-325

Antoncic, B. a. H. R., 2001. Intrapreneurship: Construct refinement and cross-cultural validation. Journal of business venturing, 16(5), pp. 495-527.

Antoncic, B. \& Hisrich, R. D., 2000. Intrapreneurship modeling in transition economies: A comparison of Slovenia and the United States. Journal of Developmental Entrepreneurship, 5(1), p. 21.

Antoncic, B. \& Hisrich, R. D., 2004. Corporate entrepreneurship contingencies and organizational wealth creation. Journal of Management Development, 23(6), pp. 518-550.

Arasti, Z., Zandi, F. \& Bahmani, N., 2014. Business failure factors in Iranian SMEs: Do successful and unsuccessful entrepreneurs have different viewpoints?. Journal of Global Entrepreneurship Research, 4(1), pp. 1-14.

Armesh , H., Kahkha , A. O. \& Kahrazeh, A., 2014. Corporate Entrepreneurship and Firm Performance Important Role of Small and Medium Enterprise. International Journal of Academic Research in Business and Social Sciences, 4(6), pp. 8-25.

Audretsch, D. B. \& Keilbach, M., 2003. Entrepreneurship Capital and Economic Performance Regional Studies. 38(8).

Banerjee , P., 2003. Some indicators of dynamic technological competencies: understanding of Indian software managers. Technovation, 23(7), p. 593-602.

Bruton, G. D., Ahlstrom, D. \& Obloj, K., 2008. Entrepreneurship in emerging economies: Where are we today and where should the research go in the future. Entrepreneurship theory and practice, 32(1), pp. 1-14.

Bulut, Z. \& Yilmaz, H., 2008. Determination of landscape beauties through visual quality assessment method: a case study for Kemaliye (Erzincan/Turkey). Environmental Monitoring and Assessment, 141(1), p. 121-129.

Burgelman, R. A., 1983. A Process Model of Internal Corporate Venturing in the Diversified Major Firm. Administrative Science Quarterly, 28(2), pp. 223244.

Bygrave, W. a. H. C., 1991. Theorizing about entrepreneurship. Entrepreneurship theory and Practice, 16(2), pp. 13-22. 
Chen, M. H. \& Cangahuala, G., 2010. Corporate entrepreneurship environment and organizational performance in technology manufacturing sector. In PICMET 2010 TECHNOLOGY MANAGEMENT FOR GLOBAL ECONOMIC GROWTH, pp. 1-9.

Chiva, R. a. A. J., 2009. Investment in design and firm performance: The mediating role of design management. Journal of Product Innovation Management, 26(4), pp. 424-440.

Cooper, R. G., Edgett, S. J. \& Kleinschmidt, E. J., 2004. BENCHMARKING BEST NPD PRACTICES-I. Research Technology Management, 47(1), pp. 31-43.

Covin , J. G. \& Slevin , D. P., 1991. A Conceptual Model of Entrepreneurship as Firm Behavior. Social science research network, 16(1), pp. 7-25.

Damanpour, F., 1991. Organizational innovation: A meta-analysis of effects of determinants and moderators. Academy of management journal, 34(3), pp. 555-590.

Danneels, E., 2007. The process of technological competence leveraging.. Strategic Management Journal, 28(5), pp. 511-533.

Darroch, J., 2005. Knowledge management, innovation and firm performance. Journal of knowledge management, 9(3), pp. 101-115.

Dess, G. G. et al., 2003. Emerging Issues in Corporate Entrepreneurship. Journal of management, 29(3), pp. 351-378.

Edelman, L. \& Yli-Renko , H., 2010. The Impact of Environment and Entrepreneurial Perceptions on Venture-Creation Efforts: Bridging the Discovery and Creation Views of Entrepreneurship. Entrepreneurship theory and practice, 34(5), p. 833-856.

Elangovan, A., 2001. Causal ordering of stress, satisfaction and commitment, and intention to quit: a structural equations analysis. Leadership \& Organization Development Journal, 22(4), pp. 159-165.
Fakour, B. \& Ansari, M. T., 2009. Analysis of inhibiting and provocation factors for innovation in small firms selected in Iran.. Entrepreneur Development, 1(4), pp. 39-65.

Gantsho, M., 2006. Corporate Entrepreneurship in Development Finance Institutions. Doctoral dissertation, University of Pretoria.

García-Morales, V. J.-B. M. a. G.-G. L., 2012 Transformational leadership influence on organizational performance through organizational learning and innovation. Journal of Business Research, 65(7), pp. 1040-1050

Gresov \& Drazin, F. P. C., 2007. A set-theoretic approach to organizational configurations. Academy of management review, 32(4), pp. 1180-1119.

Guth, W. D. \& Ginsberg, A., 1990. Corporate Entrepreneurship. Strategic Management Journal, Volume 11, pp. 5-15.

Hair, J. F., 2010. Multivariate data analysis. Pearson College Division.

Hanan, M., 1976. Venturing corporations-think small to stay strong. Harvard Business Review, 54(3), pp. $139-148$

Haynie, J. M., Shepherd, D., Mosakowski, E. \& Earley, P. C., 2010. A situated metacognitive model of the entrepreneurial mindset. Journal of business venturing, 25(2), pp. 217-229.

Henard, D. \& Szymanski, D., 2001. Why some new products are more successful than others. Journal of marketing Research, 38(3), pp. 362-375.

Hisrich, R. a. P. M., 1984. Internal venturing in large corporations. Frontiers of entrepreneurship research, pp. 321-346.

Hitt, M. A., Ireland, R. D., Camp, S. M. \& Sexton, D. L., 2001. Strategic entrepreneurship: Entrepreneurial strategies for wealth creation. Strategic management journal, 22(6-7), pp. 479-491. 
Hitt, M. A., Ireland, R. D. \& Sirmon, D. G., 2011. Strategic entrepreneurship: creating value for individuals, organizations, and society. The Academy of Management Perspectives, 25(2), pp. 57-75.

Hornsby, J. S., Kuratko, D. F., Shepherd, D. A. \& Bott, J. P., 2009. Managers' corporate entrepreneurial actions: Examining perception and position. Journal of Business Venturing, 24(3), pp. 236-247.

Hornsby, J. S., Kuratko, D. F. \& Zahra, S. A., 2002. Middle managers' perception of the internal environment for corporate entrepreneurship: assessing a measurement scale. Journal of Business Venturing, 17(3), p. 253-273.

Hornsby, J. S., Montagno, R. V. \& Kuratko, D. F., 1990. Developing an intrapreneurial assessment instrument for an effective corporate entrepreneurial environment. Strategic management journal, 11(5), pp. 49-58.

Hurmelinna-Laukkanen, P., Sainio, L.-M. \& Jauhiainen, T., 2008. Appropriability regime for radical and incremental innovations. R\&D Management, 38(3), p. $278-289$.

Ireland , R. D. \& Webb, J. W., 2007. A CrossDisciplinary Exploration of Entrepreneurship Research. Journal of Management, 33(6), pp. 891-927.

Irland, D. \& Webb, J., 2002. A Cross-Disciplinary Exploration of Entrepreneurship Research. Journal of Mangement, Volume 33.

Jennings, D. F. \& Seaman , S. L., 1990. Aggressiveness of response to new business opportunities following deregulation: An empirical study of established financial firms. Journal of Business Venturing, 5(3), pp. 177-189.

Jogaratnam, G. a. C.-Y. T. E., 2006. Entrepreneurial orientation and the structuring of organizations: performance evidence from the Asian hotel industry. International Journal of Contemporary Hospitality Management, 18(6), pp. 454-468.
Kamyabi, Y. \& Devi, S., 2010. The impact of advisory services on Iranian SME performance: An empirical investigation of the role of professional accountants. S.Afr.J.Bus.Manage, 43(2), pp. 61-72.

Kanter, R., 1985. Supporting innovation and venture development in established companies. Journal of business venturing, 1(1), pp. 47-60.

Kanter, R. a. R. L., 1991. Engines of progress: Designing and running entrepreneurial vehicles in established companies. The enter-prize program at Ohio Bell, 6(3), pp. 209-229.

Katsikea, E. T. M. P. N. a. K. J., 2011. The effects of organizational structure and job characteristics on export sales managers' job satisfaction and organizational commitment. Journal of World Business, 46(2), pp. 221-233.

Kenney, M. \& Mujtaba, B., 2007. Understanding corporate entrepreneurship and development: A practitioner view of organizational intrapreneurship. Journal of Applied Management and Entrepreneurship, 12(3), p. 73.

Khanna, T. \& Palepu, K. G., 2011. Winning in Emerging Markets: Spotting and Responding to Institutional Voids. WORLD FINANCIAL REVIEW , pp. 18-20.

Knight , G. A., 1997. Cross-cultural reliability and validity of a scale to measure firm entrepreneurial orientation. Journal of Business Venturing, 12(3), pp. 213-225.

Krejcie, R. a. M. D., 1970 . Determining sample size for research activities. Educ psychol meas, 30(3), pp. 607-610.

Kuratko, D. a. H. R., 2004. Innovation and the entrepreneur. Entrepreneurship, 6th edn. Mason, $\mathrm{OH}$ : Thomson, pp. 138-50.

Kuratko, D. M. R. a. H. J., 1990. Developing an intrapreneurial assessment instrument for an effective 
corporate entrepreneurial environment. Strategic management journal, 11(5), pp. 49-58.

Kyrgidou, L. \& Hughes, M., 2010. Strategic entrepreneurship: origins, core elements and research directions. European Business Review, 22(1), pp. 43 63.

Landstrom, H., 2005. Pioneers in Entrepreneurship and Small Business Research. Springer, pp. 31-39.

Lee, D. Y. \& Pennings, 2005. The Essence of Strategic Leadership: Managing human and social capital, s.l.: s.n.

Lee, D. Y. \& Tsang, E. W. K., 2001. The effects of entrepreneurial personality, background and network activities on venture growth. Journal of Management Studies, 38(4), p. 583-602.

Lumpkin, G. T. \& Dess, G. G., 1996. Clarifying the Entrepreneurial Orientation Construct and Linking It to Performance. The Academy of Management Review, 21(1), pp. 135-172.

Lumpkin, T. G., Seibert, S. E. \& Zhao, H., 2010. The relationship of personality to entrepreneurial intentions and performance: A meta-analytic review. Journal of management, 36(2), pp. 381-404..

Luo M, P. \& Covin, J. G., 2005. Exploring the practice of corporate venturing: some common forms and their organizational implications. Entrepreneurship: Theory \& Practice, 26(3), pp. 21327.

MacMillan, I. B. Z. a. N. P., 1984. Obstacles and Experiences in Corporate Ventures, s.l.: New York University, Center for Entrepreneurial Studies.

Manafi, M. \& Subramaniam, I., 2015. Relationship between Human Resources Management Practices, Transformational Leadership, and Knowledge Sharing on Innovation in Iranian Electronic Industry. Asian Social Science, 11(10), p. 358.
Minguzzi , A. \& Passaro , R., 2001. The network of relationships between the economic environment and the entrepreneurial culture in small firms. Journal of Business Venturing, 16(2), p. 181-207.

Mojica, M., Gebremedhin, T. \& Schaeffer, P., 2010. A county-level assessment of entrepreneurship and economic development in Appalachia using simultaneous equations. Journal of Developmental Entrepreneurship, 15(01), pp. 3-18.

Morgan, R. A. et al., 2006. Cancer Regression in Patients After Transfer of Genetically Engineered Lymphocytes. NIH Public Access, 314(5796), pp. 126129.

Morris, M. H. \& Kuratko, D. F., 2002. Corporate Entrepreneurship. Orlando, Florida: Harcourt College Publishers.

Nunnally, J. C., 1978. Psychornetric theory, New York: s.n.

Pearce II, J. A., Fritz, D. A. \& Davis , P. S., 2010. Entrepreneurial Orientation and the Performance of Religious Congregations as Predicted by Rational Choice Theory. Entrepreneurship Theory and Practice, 34(1), p. 219-248.

Peterson, R. a. B. D., 1971. Entrepreneurship in organizations: Evidence from the popular music industry. Administrative Science Quarterly, 16(1), pp. 97-106.

Pinchot, G., 2002. III (1985). Intrapreneuring, New York, NY: Intrapreneuring.

Sadler, R., 2000. Corporate entrepreneurship in the public sector: the dance of the chameleon. Australian Journal of Public Administration, 59(2), pp. 25-43.

Sadler, R., 2000. Corporate entrepreneurship in the public sector: the dance of the chameleon. Australian Journal of Public Administration, 59(2), pp. 25-43. 
Sathe, V., 1985. Culture and related corporate realities: text, cases, and readings on organizational entry, establishment, and change Homewood.. Ill.: $R D$ Irwin..

Schollhammer, H., 1981. The efficacy of internal corporate entrepreneurship strategies. Frontiers of entrepreneurship research, pp. 451-456.

Schollhammer, H., 1982. Internal corporate entrepreneurship. Encyclopedia of entrepreneurship, Issue 209, p. 223.

Shane, S. \& Venkataraman, S., 2000. The Promise of Entrepreneurship as a Field of Research. ACAD MANAGE REV, 25(1), pp. 217-226.

Sharma, P. a. C. S., 1999. Toward a reconciliation of the definitional issues in the field of corporate entrepreneurship. In Entrepreneurship , Berlin: Springer Berlin Heidelberg.

Soonhee, K., 2009. Managerial leadership, the Climate for Creativity and innovation, and a culture of innovation and Performance-Driven in local Government. In PMRA conference, pp. 1-2.

Stevenson, H. H. \& Jarillo, J. C., 1990. A Paradigm of Entrepreneurship: Entrepreneurial Management. Strategic Management Journal, Volume 11, pp. 17-27.

Tabarsa, T. J. S. a. A. A., 2011. Mechanical and physical properties of wheat straw boards bonded with a tannin modified phenol-formaldehyde adhesive. Composites Part B: Engineering, 42(2), pp. 176-180.

Terziovski, M., 2010. Innovation practice and its performance implications in small and medium enterprises (SMEs) in the manufacturing sector: a resource-based view.. Strategic Management Journal, 31(8), pp. 892-902.

Turró, A., Urbano, D. \& Peris-Ortiz, M., 2014. Culture and innovation: The moderating effect of cultural values on corporate entrepreneurship.
Technological Forecasting and Social Change, Volume 88, pp. 360-369.

Vesper, K., 1984. Three faces of corporate entrepreneurship: A pilot study. University of Washington. Graduate School of Business.

Villiers-Scheepers, M., 2012. Antecedents of strategic. European Business Review, 24(5), pp. 400424.

Wang, Y. \& Zhang, X., 2009. Journal of Chinese Entrepreneurship. Operationalization of corporate entrepreneurship and its performance implications in China: An empirical study, 1(1), pp. 8 - 20.

Weeks, J. L., 2008. Autocratic Audience Costs: Regime Type and Signaling Resolve. International Organization, 62(1), pp. 35-64.

Yilmaz , C., Alpkan , L. \& Ergun , E., 2005. Cultural determinants of customer- and learningoriented value systems and their joint effects on firm performance. Journal of Business Research, 58(10), p. 1340-1352.

You \& Liu, 2008. Market Orientation and Planning Flexibility in SMEs Performance Implications and an Empirical Investigation. International Small Business Journal, 25(2), pp. 152-172.

Zahra, S., 1991. Predictors and financial outcomes of corporate entrepreneurship: An exploratory study. Journal of business venturing, 6(4), pp. 259-285.

Zahra, S., 1993. Environment, corporate entrepreneurship, and financial performance: A taxonomic approach. Journal of business venturing, 8(4), pp. 319-340.

Zahra, S. A., 2007. Contextualizing theory building in entrepreneurship research. Journal of Business Venturing, 22(3), pp. 443-452.

Zahra, S. A., 2010. Harvesting family firms' organizational social capital: A relational perspective. Journal of Management Studies, 47(2), pp. 345-366. 
International Journal of Science and Engineering Applications

Volume 5 Issue 10, 2016, ISSN-2319-7560 (Online)

Zahra, S. A., Filatotchev, I. \& Wright, M., 2009. How do threshold firms sustain corporate entrepreneurship? The role of boards and absorptive capacity. Journal of Business Venturing, 24(3), pp. 248260.

Zahra, S. a. K. B., 2005. Technological Resources And New Firm Growth: A Comparison Of Start-Up And Adolescent Ventures\$. Research in the Sociology of Work, 15(5), pp. 101-122.
Zahra, S. A., Neubaum, D. O. \& Huse, M., 2000. Entrepreneurship in Medium-Size Companies: Exploring the Effects of Ownership and Governance Systems. Journal of Management, 26(5), pp. 947-976. 